\title{
DIE VERSORGING VAN ONS PASIËNTE VANUIT 'N SIELKUNDIGE OOGPUNT - FEIT OF LEGENDE
}

\author{
Professor A.M. Venter
}

\author{
Hoof, Departement Verpleegkunde \\ Universiteit van Wes-Kaapland
}

\section{Inleiding}

$\mathbf{V}$ ANWEË die feit dat daar tot dusver weining indien enige navorsing in die R.S.A. gedoen is oor die sielkundige versorging van ons pasiënte, is dit onmoontlik om 'n bepaalde standpunt in te neem t.o.v. die feit of dit ' $n$ legende is al dan nie.

'n Vraag wat by my opkom is: wat word met sielkundig in hierdie konteks bedoel? Dat die verpleegkundige sekere sielkundige grondhoudings in die praktyk sal toepas? Indien wel, is dit beswaarlik moontlik dat sy in staat sal wees om die pasiënt se probleme vanuit 'n sielkundige oogpunt te kan oplos met die beperkte teoretiese kennis waaroor sy beskik. Indien daar egter empatie, meevoeling en simpatie met pasiënte bedoel word, kan daar onomwonde verklaar word dat dit in mindere of meerdere mate by alle verpleegkundiges teenwoordig is. "Empathy is not innate: it is a learned response which we acquire by listening. Our brains, like computers must have intake before they can give any valuable output"' (Mac Millan-Brett, 1979).

Die kuns wat elke verpleegkundige in hierdie verband moet bemeester alvorens sy enige noemenswaardige bydrae tot die pasiënt se welsyn kan maak, is om te kan luister en betekenisvolle intellektuele waarnemings t.o.v. die pasiënt se doen en late te maak. Ongelukkig is dit so in die eeu waarin ons lewe, dat baie mense hulself nie die tyd gun om te luister, nie net na wat andere te sê het nie, maar ook na dit wat hulle nie sê nie. Dit dui op 'n gebrek aan sensitiwiteit en kommunikasie. Elkeen is so vasgevang in sy gedagtes om homself voor te berei op dit wat hy wil kwytraak, dat die inligting wat die ander persoon wil oordra, totaal by hom verbygaan. "Unless understanding is successfully communicated to the other, little value will accrue from the helpers' internal knowledge of the feelings and experience of the other'. (Redaksioneel, Nursing Research, Nov./Dec., 1977).

Is die sielkunde ter sprake by die versorging van ons pasiënte?

In die sielkunde wentel alles om die individu - sy behoeftes, begeertes, emosies, persoonlikheid ens. Die pasiënt is in die eerste plek ook individu met al die genoemde eienskappe. In die verpleegkunde is die siek individu ook die middelpunt van al ons versorging die kern van al ons aktiwiteite as verpleegkundiges. Dit is dus vanselfsprekend dat die bestudering van die psige van die individu onlosmaaklik verbonde is en deel uitmak van die behandeling van die individu.

'n Beroemde geneesheer, Sir William Osler, het reeds meer as ' $n$ eeu gelede die stelling gemaak dat kennis van die pasient as mens belangriker is as die siekte waaraan hy ly. Hiermee het hy gestalte gegee aan die begrip dat persoonlikheidsreaksies dikwels die siektebeeld oorskadu; dat die eienskappe van die menslike persoonlikheid nie uit die oog verloor moet word wanneer kliniese waarnemings met die oog op diagnose gemaak word nie.

In ons eie tyd word hierdie stelling van Osler ál meer bevestig. Die omvang van die probleem word beklemtoon deur 'n ondersoek wat die National Institute of Health 'n paar jaar gelede in Amerika uitgevoer het. "Uit 'n totaal van 1156 geneeshere en spesialiteite, wat ondervra is oor die rol van sielkundige faktore in die algemene siektetoestande, waarmee hulle te doen gekry het in die praktyk, het nie minder as $84 \%$ bevestig dat hulle met emosionele reaksies by hulle pasiënte te make kry, van 'n aard wat terapie verg"'. (v.d. Merwe, 1979).

Tydens 'n siektetoestand ervaar die pasiënt ernstige emosionele ontwrigting - in so 'n mate dat 'n persoonlikheidskrisis kan ontstaan a.g.v. die oordrewe gevoelens van angs en onsekerheid. Schiller het t.o.v. angs die volgende gesê: "Nothing else in the world can make man unhappy but fear. The misfortune we suffer is seldom if ever as bad as that which we fear". (Woolf, 1979). Vanweë hierdie ontsettende angsgevoelens reageer die pasiënt op oordrewe wyse op elke prikkel die geneesheer steek die "ergste" vir hom weg; die verpleegkundige is onnodig ligsinnig en reageer nie soos hy verwag sy moet op sy ernstige toestand reageer nie; hy sal liewers nie iets vra as hy dit nodig het nie, want hy voel hy is 'n oorlas vir almal, ens. Teenoor al hierdie eise wat die pasiënt stel, staan die verpleegkundige soms heeltemal magteloos.

Indien daar van die verpleegkundige vereis word om 'n sielkundige benadering teenoor pasiënte/kliënte te openbaar, moet daar in gedagte gehou word dat sy alle lae van die sameleweing moet hanteer - persone wat dikwels uiters ongemanierd is en wat haar geduld tot die uiterste beproef. Verder het sy ook te make met die 
pasiënt/kliënt vanaf geboorte tot in sy bejaardheid deur alle stadia van ontwikkeling.

Indien hospitalisasie die volwassene emosioneel ontwrig, is dit vir die jong kind nog soveel erger aangesien hy emosioneel baie meer afhanklik is en gevolglik geensins oor dieselfde mate van selfbeheer beskik nie. Navorsing het getoon dat waar die personeel van 'n hospitaal nie sielkundige voorligting ontvang t.o.v. optrede teenoor die kind nie, $92 \%$ van die kinders tekens van emosionele spanning en disorganisasie van gedrag in die hospitaal ontwikkel.

By die versorging van die bejaarde is die inboeseming van 'n gevoel van waarde en relatiewe selfstandigheid en van fisiese en emosionele welsyn dikwels van groter belang as ingewikkelde tegniese verpleegprosedures. Die hallusinasies en delusies wat soms by hierdie pasiënte voorkom, verg uiterste aanpassings van die verpleegpersoneel en hulle kan hul dikwels nie vereenselwig met die gedagte dat dit eendag vir hulle ook beskore mag wees nie.

Is die verpleegkundige toegerus vir haar taak t.o.v. sielkundige versorging van haar pasiënte?

Dit is geen legende dat die volgende opvoedingsaspekte binne die beroep gehandhaaf word nie.

1. Professionele verpleegkundiges word sonder twyfel vir 'n mensgesentreerde taak toegerus, dog in 'n meerdere mate t.o.v. die biologiese en fisiologiese aspekte vir die geestesgesondheid van die pasiënt. As gevolg van die groei van die wetenskap wat ons beoefen, word die fisiese sy van die taak en die doel outomaties die eerste prioriteit gegun.

2. Hierdie uiters sensitiewe deel van die globale taak word nie slegs teoreties ingeprent nie, maar daar word steeds meer klem gelê op die volgehoue evaluering daarvan binne die roluitoefeningsdimensie.

3. Die inskakeling van die geesteswetenskappe as verpligte vakrigtings vir basiese en na-basiese kursusse in die laaste dekade moet sonder twyfel die praktyk positief onderskraag.

Faktore wat moontlik stremmend kan inwerk op die sielkundige versorging wat daar van verpleegkundiges verwag word.

Die studentverpleegkundige

- Kan daar in alle eerlikheid en opregtheid verwag word dat 'n adolessent werklik oor die vermoe beskik om 'n pasiënt te versorg uit 'n absolute altruïstiese oogpunt d.w.s. kan sy hom soveel warmte, aanvaarding, empatie en deernis gee soos wat ons as kritiese volwassenes verwag?

- Word daar ooit genoeg aandag geskenk aan die veelvuldigheid van probleme waarmee sy as adolessent te kampe het? Is dit nie 'n normale reaksie dat sy haar eerstens daarmee besig gaan hou om haar eie probleme uit te stryk en daarna eers sal dink aan die behoeftes van die siek persoon nie?

- Word die teorie van die geesteswetenskappe ooit geïnternaliseer of is dit maar net nog ' $n$ kursus waarin 'n eksamen afgelê moet word?
- Selfvertroue versus angs - beskik die studentverpleegkundige werklik oor die nodige selfvertroue om pasiënte se vrae m.b.t. bv. sy siekte te kan hanteer of is sy so beangs oor wat die geneesheer wil hê die pasiënt moet weet en wat nie, dat sy die pasiënt se vrae ignoreer? Hierdie onsekerheid en angs kring ook verder uit t.o.v. die vreemde omgewing waarin sy haar bevind, die kompleksiteit van duur apparaat wat sy moet hanteer en die verantwoordelikheid wat elke taak wat sy moet verrig, meebring.

- Hoeveel belangstelling toon die student in die verpleegkundeberoep? Was dit haar eie keuse om tot die beroep toe te tree of was dit moontlik haar ouers se keuse? In hierdie geval moet die totale verpleegsorg - fisies sowel as psigies skade ly.

- Faktore soos etnisiteit, houdings en vooroordele is ook van die grootste belang. Is dit moontlik dat 'n mens sekere dinge kan afleer wat sedert die kinderdae geïnternaliseer is? Opvoeding, agtergrond, sosio-ekonomiese status en houdings is baie nou verbonde hieraan en is almal betrokke by die vorming van die persoonlikheid van die individu. Om 'n persoonlikheidsverandering te weeg te bring is ' $n$ langdurige en intensiewe proses.

- Onsimpatieke benadering van geneeshere en senior verpleegpersoneel is ' $n$ algemene klagte by die jong studentverpleegkundige. Dit is ' $n$ feit dat 'n mens net liefde, warmte, ondersteuning en meegevoel kan gee namate jy dit self ontvang en beleef.

- Word daar werklik genoeg gedoen t.o.v. die oriëntasie van die nuweling? Aan wie word hierdie taak opgedra en hoe kwyt die persoon hom daarvan?

\section{Binne die beroep self}

- In akute hospitale is die pasiënte-omset baie hoog, dan is daar net nie genoeg tyd vir die verpleegkundige om betrokke te raak met die probleme van die pasiënte nie.

- die snelle veranderings en vooruitgang op mediese gebied in die spesialiteitshospitale, is oorweldigend.

- Soms word die akademie in universiteitsgeaffilieerde hospitale oorbeklemtoon.

- Sporadies kom daar fisiese tekorte aan personeel voor, wat tyd vir sielkundige betrokkenheid grootliks beperk.

- Onvoldoende of ontoereikende kwalifikasies van personeel veral in afgeleẻ of afgesonderde areas.

- Gebrek aan 'n voldoende akkreditasiesisteem by hospitale in die Republiek waarvolgens ' $n$ "ou hand" weer "nuut" gemaak word. Hier moet daarop gelet word dat personeel wat onseker van hulself voel, dikwels op 'n aggressiewe wyse reageer. Van 'n simpatieke of empatiese houding kom daar dan weining tereg. 
- Die verpleegkundige se rol word al hoe meer instrumenteel alhoewel die ekspressiewe verwagtings onveranderd gekoppel bly aan die rol.

- Die administratiewe en bestuursfunksie van die professionele verpleegkundige neem dikwels so 'n omvang aan dat sy net nie voldoende tyd kry om aan haar opvoedingstaak te wy nie.

Tog is dit nie reg om $u$ te laat met die gedagte dat alle faktore meewerk om die sielkundige versorging van die nasiënt te belemmer nie. Dit is so dat 'n mens net sowel positief daaroor kan redeneer. Is dit nie so dat dit juis in die spesialisasies van die universiteitshospitale is waar personeel beter toegerus word vir die instrumentele taak nie? Dit is ongefundeerd om te redeneer dat die verpleegleier, hetsy dit as bestuurder of as opvoeder, noodwendig net op die biologiese vlak van menslike entiteit funksioneer en dat daar op psigiese of sosiale vlakke geen of weinig wisselwerking tussen haar en haar pasiënt/kliënt bestaan nie.

Medelye en deernis is ' $n$ uiters belangrike faktor in verpleegkunde, maar veral in sekere hospitaalafdelings, bv. die intensiewe sorgeenheid. Die onverbiddelike atmosfeer in hierdie departement wat gepaard gaan met die hoë peil van kliniese vaardigheid en hantering van ingewikkelde apparatuur ten einde die mens se lewe te behou en te bewaar, bring mee dat daar vir simpatie en empatie min tyd gelaat word. Die tegnologie van die versorging van die fisieke toestand vereis soveel aandag en tyd dat totale versorging nie kan plaasvind nie en die psigiese toestand die deel is wat moet skade ly.

Nogtans het ek in die intensiewe sorg-eenhede van 'n groot hospitaal 'n uiters fyn sensiwiteit, intelligente behoeftebepaling, groot empatie, onderskraging en ondersteuning by die verpleegkundiges teenoor die pasiënt geëvalueer. Dit is ook in hierdie eenhede waar die pasiënt so ' $n$ intense gevoel van sekuriteit ervaar wat te danke is aan die bekwaamheid wat spruit uit die hoogs gespesialiseerde kennis en empatiese benadering deur die verpleegpersoneel, dat dit met groot huwering is dat die pasiënt toestem om na 'n ander afdeling geskuif te word wanneer sy toestand dit toelaat.

In sekere opleidingshospitale bestaan ook die gebruik dat van die operasiesaalspanlede die pasiënt preoperatief moet besoek ten einde hom/haar gerus te stel vir die operasie wat ondergaan moet word. Dit is so dat een van die grootste spanningsituasies waarin enige persoon kan verkeer, die tydperk is wat 'n operasie voorafgaan. Hierdie spanning word veral veroorsaak deur die onbekende wat voorlê en dan veral t.o.v. die narkose wat ondergaan moet word. Gerusstelling en em- patie met die pasiënt, veral deur iemand afkomstig uit daardie onbekende wêreld, het 'n besondere groot waarde in die verligting van die angstoestand wat dikwels aan dissosiasie van bewussynsfunksies grens.

Laaste maar nie die minste nie is die bewys van die sielkundige benadering van verpleegkundiges in algemene hospitaalafdelings. Feitlik daagliks verskyn briewe van waardering in tydskrifte en koerante, en briewe en telefoonoproepe van dank en prys vir verpleegkundige dienste word in hul honderdtalle deur hoofde van hospitale ontvang.

Indien al die voorafgaande faktore in ag geneem word, is ek van mening dat die verpleegkundige in die huidige tydvak haar baie goed van haar taak kwyt en dat dit selfs sal verbeter namate die leiers in die beroep meer klem op die sielkundige bendadering en individualiteit van pasiënte/kliënte lê.

Ten einde die waarde-oordele en veralgemenings t.o.v. hierdie onderwerp te reduseer tot 'n konkrete, betroubare en geldige gevolgtrekking, sou 'n meer realistiese vertrekpunt, dié van ondersoek en navorsing, die enigste oplossing bied.

Mag ons as verpleegkundiges in die R.S.A. steeds en in toenemende mate daarteen waak om ons pasiënte die gevoel van isolasie wat Job beleef het, te laat ondervind.

“. . my brothers stand aloof from me and my relatives take care to avoid me, my kindred and friends have all gone away and the guests in my house have forgotten me", (Job 19 : 13-15).

\begin{tabular}{|c|c|}
\hline onnelys & \\
\hline Alexander, E.L. & $\begin{array}{l}\text { Nursing Administration in hospital health } \\
\text { care systems, St. Louis: C.V. Mosby., } 1978 .\end{array}$ \\
\hline Mac Millan, Brett. & $\begin{array}{l}\text { The nurse and the chemotherapy patient: a } \\
\text { vital role in emotional support. Canadian } \\
\text { Nurse, June } 1979 \text {. }\end{array}$ \\
\hline Redaksioneel. & $\begin{array}{l}\text { Nurse, June } 1979 . \\
\text { Relationship of perceived empathy to nuises' } \\
\text { communication. Nursing Research, 1976, } 26 . \\
\text { 6, p432. }\end{array}$ \\
\hline Tobin. H.M.; Yoder-Wise, P.S.; Hull, P.K. & $\begin{array}{l}\text { The process of staff development Tools for } \\
\text { change. Si. Louis: C.V. Mosby., } 1979 .\end{array}$ \\
\hline vid. Merwe, A.B. & $\begin{array}{l}\text { Die sielkundige behoeftes van die pasiënt. } \\
\text { Simposium Universiteit Stellenbosch en } \\
\text { Tygerberg-Hospitaal. Junie 1979. }\end{array}$ \\
\hline Woolf, J & $\begin{array}{l}\text { Nurse could you care more! Nursing } 1 \text { imes, } \\
\text { June } 7,1979 \text {. }\end{array}$ \\
\hline
\end{tabular}

